\title{
分析化学理论教学中课程思政的实践与探索
}

\author{
王焕锋，李玉玲*，王利平，李晓静，李靖靖，王岗
}

郑州工程技术学院化工食品学院, 郑州 450044

摘要: 以分析化学理论教学中的课程思政为主题, 概述了分析化学课程思政建设的研究现状; 从思政目标的建立、 课程思政的教学探索、教师素养三方面对专业课程思政进行了实践探索; 通过精准备课、优化课堂互动、构建反馈 渠道等方式, 实现知行合一的课程思政教学目标。

关键词: 课程思政; 分析化学; 专业基础课; 理论教学

中图分类号: G64; O6

\section{Practice and Exploration on Course Ideology and Politics in Theory Teaching of Analytical Chemistry}

\author{
Huanfeng Wang, Yuling Li ${ }^{*}$, Liping Wang, Xiaojing Li, Jingjing Li, Lan Wang \\ College of Chemical and Food, Zhengzhou University of Technology, Zhengzhou 450044, China.
}

\begin{abstract}
This paper focuses on the topic of course ideology and politics in analytical chemistry teaching, and the research status on this topic has been summarized. The practical exploration has been carried out on the establishment of the educational goal, teaching exploration and the teachers' accomplishment. The ideological and political goal of integrating knowledge and action is expected to be realized by the ways of precise lecture preparation, optimization of classroom interaction and construction of feedback channels.
\end{abstract}

Key Words: Course ideology and politics; Analytical chemistry; Specialized basic course; Theory teaching

全面推进课程思政建设、实现思政教育与专业教学的有机融合, 建立社会主义核心价值观引领的 知识传授和人才能力培养模式, 是新时期我国高等教育的人才培养方略。作为课程思政的主要依托, 专业课程思政教学需将教育与科学精神的培养结合起来, 实现 “立德树人” “ “课程育人” 的统一, 培养学生勇于创新的科研精神和创造性思辨能力，激发学生科技报国的家国情怀和使命担当 ${ }^{[1,2]}$ 。

作为化学、化工、食品、医药的专业基础课程之一, 分析化学课程具有完备的知识架构体系和 丰富的价值理念; 课程的教学重点在于解决如何探知物质中的组分及其含量问题, 在医疗卫生、工 业生产、食品质量检测等领域发挥着极其重要的作用。因此, 充分挖掘分析化学理论教学中的思政 元素, 并将其渗透于课堂教学内容, 强化学生专业伦理教育, 激发学生追求真理、勇攀高峰的使命 感, 对实现我国高等教育厚植爱国主义情怀的人才培养目标具有促进意义。本文结合课程特点和授 课学时要求, 从精准备课、优化课堂互动、完善反馈渠道、教学案例分析以及教师素养等方面对分 析化学理论教学的课程思政进行了探索与实践。

收稿: 2021-02-24; 录用: 2021-05-13; 网络发表: 2021-05-17

“通讯作者, Email: 20171031@zzut.edu.cn

基金资助: 2019 年度河南省高等学校优秀基层教学组织项目(2019-177); 2019 年度郑州工程技术学院教育教学改革研究与实践项目(就业和创新 创业教育类)项目(ZGJG2019060B); 郑州工程技术学院青年骨干教师计划项目(20180093) 


\section{1 分析化学课程思政研究现状}

在我校32理论学时的分析化学课程标准下, 如何实现少课时、多内容的学科教学与思政教育的 融合, 既能合理安排教学环节, 实现教学内容和课堂设计的层次感、实效性, 又能在课程教学中实 现课程思政的隐性渗透, 是基础化学教学亟待解决的问题。已报道的相关分析化学课程思政研究成 果中, 对开展专业课程思政的必要性、专业课与思政课的协同性、专业课程思政的教学现状、思政 教育的开展途径、教学方法和手段的创新模式、预期成效等进行了详细的分析探讨 ${ }^{[3-18]}$ 。目前研究 集中于以某一具体章节的思政教学设计或者按照思政元素涵盖的内容分类详细阐述课程思政教学案 例的设计过程, 以学科特点、社会需求、哲学思想为基础的宏观思政教育体系的构建以及课程与经 典思政元素的理论渗透等方面, 推进专业课程思政建设。结合我校分析化学教学团队 “集体备课-研 讨-拓展提升” 的教学模式, 通过思维导图、科技发展史、前沿科学研究及跨学科双人教学等多元课 堂教学手段, 充分利用线上线下教学资源, 实现教学内容与思政教育的同向同行。

\section{2 课程主旨及思政目标}

分析化学是化学、化工、食品相关专业的一门核心基础课程, 通过该课程的学习使学生掌握基 本的理论、概念、方法和计算, 准确树立 “量” 的概念, 培养学生对知识体系的全局性理解和科学 的思维习惯。本课程旨在通过坚实的专业知识体系的构建, 实现思政教育与课程教育的同向同行。 表1列举了所在分析化学教学团队在理论课程教学中的思政教学设计。

\section{表1 分析化学理论教学的思政教学设计}

\begin{tabular}{|c|c|c|}
\hline 课程内容 & 思政目标 & 思想政治教育的融入点 \\
\hline 绪论一一分析化学的任务和 & 弘扬社会主义核心价值观, 培养学生 & 以人们的衣食住行作为切入点, 通过产品质量监测、食品安全、 \\
\hline \multirow[t]{2}{*}{ 作用 } & 的社会责任感和担当意识 & 医学检验等实例, 阐明分析化学课程的意义。由一系列食品安全 \\
\hline & & 事件引发的餐桌安全问题激发学生的担当意识和社会责任感 \\
\hline 定量分析基础一一定量分析 & 培养学生严谨务实的科学精神 & 以嫦娥五号探测器成功发射并首次完成月球表面自动无人采样 \\
\hline \multirow[t]{2}{*}{ 中的误差 } & & 返地为例, 引入数据可靠性分析, 阐明高精密度、准确度的数据 \\
\hline & & 分析的重要意义 \\
\hline 酸碱滴定法——酸碱质子理 & 培养学生的批判性思维能力 & 由酸碱理论发展史, 结合 “习近平: 在科学家座谈会上的讲话” \\
\hline 论 & & 精神, 引导学生围绕科技创新展开讨论, 深化科技创新意识 \\
\hline \multirow[t]{3}{*}{ 酸碱滴定法一一两性物质 } & 培养学生勇于探索的科学精神 & 以水作为典型的两性物质为知识点, 引入人类首次在火星表面 \\
\hline & & 发现水的科技发展史, 拓展至人类对宇宙的探索, 激发学生探索 \\
\hline & & 宇宙奥秘的兴趣 \\
\hline \multirow[t]{4}{*}{ 酸碱滴定法一一共轭酸碱对 } & 培养学生民族自豪感和责任心 & 由共轭酸碱对 “酸中有碱, 碱可变酸, 相互依存, 不可分割” 的 \\
\hline & & 关系, 引入人类命运共同体的理念, 小至家庭、班级、学校, 大 \\
\hline & & 至国家、民族, 都是紧密相连不可分割的共同体, 只有风雨同 \\
\hline & & 舟、荣辱与共, 才能建设好共同的大家庭 \\
\hline \multirow[t]{3}{*}{ 酸碱滴定法一一缓冲溶液 } & 提升青少年的抗压能力 & 由缓冲溶液抵抗外加酸碱的能力扩展到人们应具备的抵抗外界 \\
\hline & & 压力的心理缓冲能力, 结合社会热点问题-青少年的抗压教育, \\
\hline & & 提升青少年的抗压能力, 构建强大的心理缓冲体系 \\
\hline 配位滴定法一一配位滴定曲 & 培养青年学生厚积薄发、行稳致远的 & 通过滴定曲线的趋势和滴定突跃引申至厚积薄发的人生哲理, \\
\hline 线 & 品质 & 成功和突破需要累积, 同时也要把握好突破的机遇 \\
\hline
\end{tabular}


大学 化 学 Univ. Chem. 2021, 36 (9), 2102038 (3 of 6)

\begin{tabular}{|c|c|c|}
\hline 课程内容 & 思政目标 & 思想政治教育的融入点 \\
\hline 配位滴定法一一应用 & 提升学生理论联系实际的能力 & $\begin{array}{l}\text { 通过配位滴定相关概念讲解, 引导学生利用所学知识解决实际 } \\
\text { 问题。如查阅文献自主设计实验测定不同水质中的总硬度 }\end{array}$ \\
\hline 氧化还原滴定法——能斯特 & 通过专业伦理教育, 引导学生树立正 & 通过能斯特方程介绍能斯特在学术科研领域的卓越贡献及其拒 \\
\hline 方程 & 确的价值观 & 绝为纳粹服务的正义精神, 引导学生树立正确的价值观 \\
\hline 氧化还原滴定法一反应进 & 倡导健康的生活方式 & 由原电池的氧化还原反应延伸至维持人体平衡的新陈代谢, 通 \\
\hline 行的程度 & & $\begin{array}{l}\text { 过改变氧化还原反应方向的影响因素引申至影响人体疾病的不 } \\
\text { 良生活方式, 倡导健康生活理念 }\end{array}$ \\
\hline 氧化还原滴定法一一应用 & 培养学生的环保意识和社会责任感 & $\begin{array}{l}\text { 通过重铭酸钾测定水中化学需氧量的方案设计, 介绍生态环境 } \\
\text { 现状, 适时引入电影《流浪地球》片段, 引发学生对地球面临的 } \\
\text { 严峻环境问题的思考 }\end{array}$ \\
\hline 沉淀滴定法 & $\begin{array}{l}\text { 提升学生利用所学知识分析问题、解 } \\
\text { 决问题的能力 }\end{array}$ & $\begin{array}{l}\text { 通过沉淀滴定相关知识的讲解, 引入工业污水处理中酸度的控 } \\
\text { 制等案例, 培养学生理论联系实际的能力 }\end{array}$ \\
\hline
\end{tabular}

\section{3 分析化学课程思政教学探索}

为实现有限课时下专业教学与课程思政的有机融合, 本文通过 “明确需求导向、实现精准备课” “优化课堂互动、实现价值引领” 和 “构建多重反馈渠道、完善课堂教学效果” 三种方式探索专业 课教学中的课程思政建设。

\section{1 明确需求导向, 实现精准备课}

明确需求导向, 实现精准备课是课程思政落到实效的前提。教育是一项在情感的互动和交流中 传递知识的活动。通过投票、问卷调查等方式(如图1所示), 获得学生寻求适应自身发展的心理需求 和成长诉求, 探索以学生需求为导向的教学设计。基于所授课程在学科体系中的基础性和系统性, 通过线上线下集体备课的模式, 挖掘课程中的思政元素, 以学生的内在需要为导向设计章节目标和 教学内容, 为专业课堂思政元素的巧妙融入奠定基础。

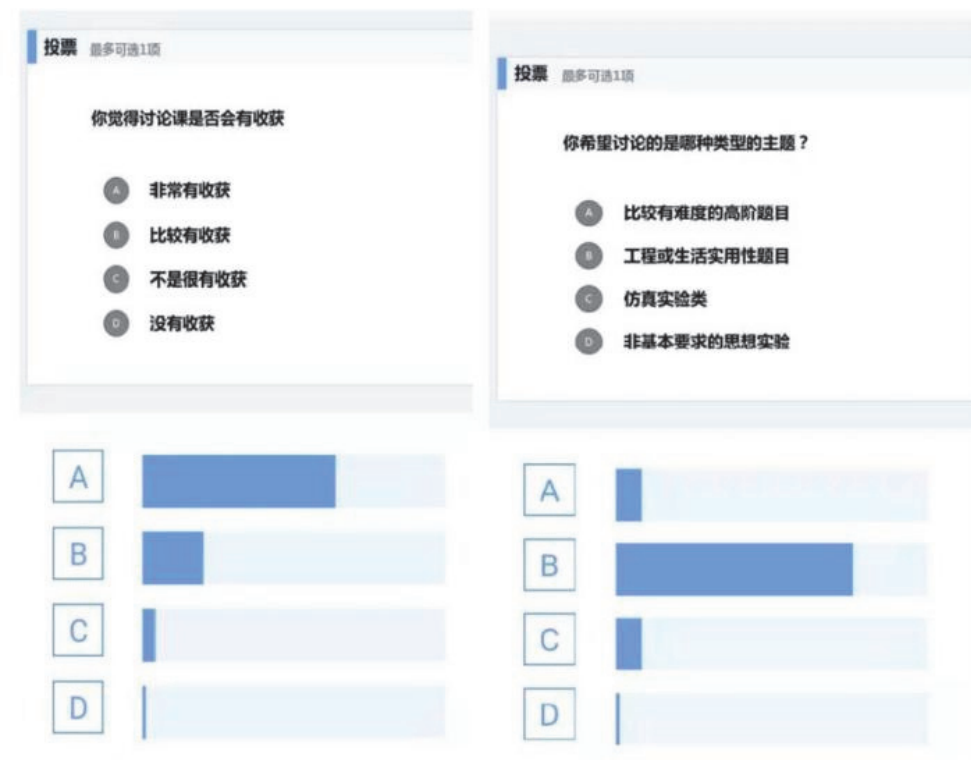

图1 基于学生需求导向的实践探索-问卷调查 
首先, 结合专业、教学内容和科研方向寻找课程思政建设的切入点, 以个人素养的提升、社会 主义核心价值观的重塑和科学探索精神的构建等方面影响学生; 如在 “绪论” 的教学设计中, 根据 不同专业的授课群体引入化工检验、食品质量控制、药物分析等实例, 以提升教学内容的趣味性和 实用性, 激发学生的学习兴趣; 引导学生树立敬业、诚信的价值理念。如在 “滴定分析方法” 章节 中, 通过对基本原理、方法和应用的基础知识的讲解, 进一步提升学生观察、思考、判断和推理的 能力, 增强其独立而准确地进行科学实验的技能, 培养严谨务实的科学态度。

其次, 根据专业学科特点选择性地将社会时事纳入授课内容, 用理论加以阐释, 实现不同学生 对同一科学理论认知的统一。如在 “定量分析过程” 教学设计中, 结合新冠病毒疫情, 通过对所运 用的荧光双位点定量PCR试剂盒检测手段的研发及检测流程的讲解, 强化学生对科学研究的理解; 同时扩展举国上下万众一心抗击疫情取得的成效, 激发学生的民族责任心, 培养学生不惧困难、奋 力向上的拼搏精神。

再者, 将国家的教育方针、人才培养标准适时融入课堂教学, 通过启发式教学提升学生对科学、 科技发展的认知。如在 “酸碱质子理论” 相关课程设计时, 通过讲述酸碱发展史渗入辩证唯物主义 思想, 引出科技的创新和突破所遵循的否定之否定规律。同时, 结合 “习近平总书记在科学家座谈 会上的重要讲话” 精神 ${ }^{11]}$, 将科技创新的理念渗入学生既有的文化认知体系, 诠释科技创新的内涵。

\section{2 优化课堂互动, 实现价值引领}

课堂教学是实现教学效果的关键环节, 课堂互动又是达成教学目标的必要保证。线上线下混合 式教学课堂可充分利用线上线下教学方式的优势, 通过中国大学慕课、哔哩哔哩网站 “分析化学” 等多种线上教学资源, 借助雨课堂教学工具, 弥补线下教学单向传输的局限性。在专业课程教学中, 摒弃 “我说你听” 的单向传递, 围绕专业特点有针对性地设计课堂教学互动主题, 达到 “润物无声” 价值引领的目的。

在 “食品质量与安全” 专业的分析化学课程设计中引入食品安全检测主题, 通过 “龙口粉丝、 苏丹红、三聚氭胺奶粉、毒胶囊” 等一系列重大食品安全事件回顾, “不同生长期果蔬酸度的测定 及发酵食品挥发酸的含量测定” 实验项目介绍, 并借助雨课堂投票、投稿等教学手段开展课堂互动, 提升学生的专业认同感, 强化学生对公正、法治、爱国、敬业、诚信的价值观的理解。在 “化学工 程与工艺” 专业的 “定量分析中的误差” 课程设计中, 与学生分享我国在探月工程中取得的成绩: 嫦娥四号实现人类首次月球背面登陆, 嫦娥五号首次实现月球表面自动无人采样返回。引导学生围 绕 “航空航天工程与科技发展” 主题, 通过分组讨论、合作探究等形式, 展开对 “不确定因素、精 密度、准确度和偏差分析” 的探讨和思考：任何一次的成功和突破都源于科技工作者对各组件的精 准设计和对各系统不确定因素、偏差分析的综合考虑, 从轨道设计到月面采样封装, 从月面起飞上 升到月球轨道交会对接与样品转移, 返回各阶段的高精密度和准确度设计为嫦娥五号圆满落月返回 提供了精准的技术保障; 再进一步拓展至执行此次探月任务背后的科技工作者, 如连接器系统指挥 员周承钰, 这些年轻的生力军已成为扛起社会责任大旗的中坚力量, 激励广大青年学生的奋斗热情。

\section{3 构建多重反馈渠道, 完善课堂教学效果}

采取多元化的评价方式和多渠道的答疑模式提升课堂教学效果。课堂学习结束后, 通过网络学 习平台发布作业, 以思维导图形式进行章节知识点的总结梳理(如图2所示), 最终建立线上平台互动、 线下课程反馈、教师集体答疑等多重渠道, 有助于学生建立有效的自我管理理念和系统的学习方法; 同时以任务驱动为载体, 鼓励学生合作开展课程设计, 培养学生的团队协作能力。如在 “缓冲溶液” 设计时, 鼓励学生通过合作探究方式构建酸碱缓冲溶液的理论模型。通过优秀作业展示、优秀笔记 分享等途径, 进一步激发学生的学习动力, 使学生真正成为学习的主人。根据课前、课中、课后线 上测试、互动评论等综合考评数据、线下小组讨论、课堂笔记、作业、课堂签到等多维考核模式实 现过程性评价, 调整成绩构成为平时考核 $60 \%$, 期末试卷成绩 $40 \%$, 试卷命题重在考查学生分析、解 决问题的能力。多重反馈渠道的建立和过程性评价体系有利于教师把握课堂教学效果, 增强学生对 
学科的认同感, 激发学生自主学习积极性。

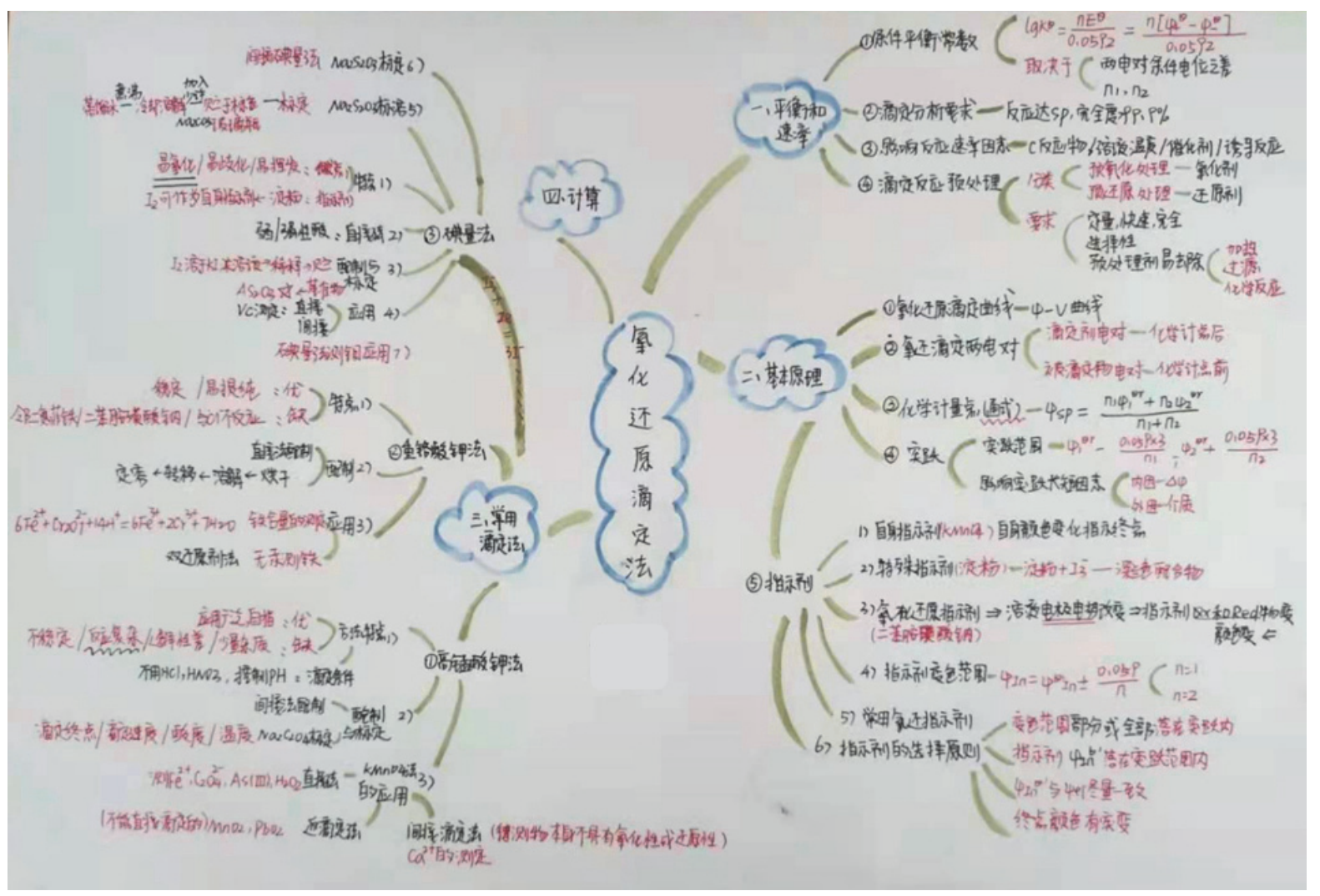

图2 思维导图实例-氧化还原滴定法章节总结

\section{4 专业课程思政的保证一一教师素养}

作为知识、思想、真理的传播者, 灵魂、生命、新人的塑造者 ${ }^{[19]}$, 教师要同时做好授业解惑和 价值观的塑造。为保证专业课程思政取得成效, 教师素养至关重要, 其中坚定的政治信仰、深厚的 专业知识、广阔的学术视野是基本保证。

坚定的政治信仰和厚重的家国情怀。作为课堂教学实施的主体, 教师的政治素养是第一位的。 “师德” 是教师素质的灵魂, 要守好师魂, 必当以身作则, 为人师表。教师通过言传身教, 用自己 的学识、思想品质和人格魅力影响学生、教育学生。只有以习近平新时代中国特色社会主义思想为 指导, 与党和国家事业发展同向同行, 才能培育出兼具底蕴深厚、学识广博、知行合一的国之栋梁。

深厚的专业沉淀。分析化学蕴含了较多的哲学思想和辩证元素, 需充分挖掘其中的思政元素并 实现与课堂教学的有机融合 ${ }^{[4,5]}$, 深厚的专业沉淀是知识传授的精准度和高度的保证, 有利于专业课 程思政教学的实现。

跨学科知识融合和前沿科学探究。跨学科教学是拓展专业知识维度的重要途径, 也是提升学生 专业素养、培养学生辨证思维能力的重要方式。因此专业课程思政教师除了扎实的专业功底, 还要

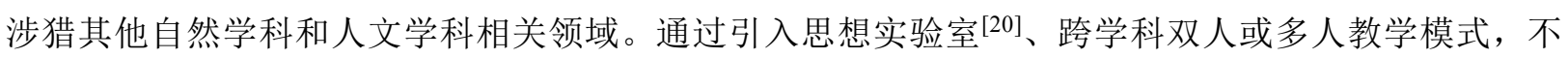
仅能培养学生的学习能力、扩充课程思政的广度和深度, 还能实现知识的集体创造, 达到学习知识 与培养创新意识的双重目的。同时将前沿科学知识适时融入教学, 提升课堂教学的前沿性和广博度。

\section{5 结语}

作为理工科课程体系中的课程思政建设的探索者, 分析化学理论教学应始终坚持知识传授、技 
能培养、价值引领和育人导向 “四位一体” 的教育理念。积极探索专业课程中蕴含的思政元素, 开 展教师讲解、学生讨论、引导学生自主发现的教学实践与探索, 将课堂转化为社会主义核心价值观 具体化、生动化的有效载体。通过专业知识的学习渗透到理想信念层面的精神指引, 以坚定的政治 信仰、高尚的人格力量、渊博的专业学识、深厚的理论功底影响学生, 引领青年学生在科学道路上 不断成长和进步。

\section{参 考 文 献}

[1] 习近平. 科学家座谈会上的讲话. [2020-09-11]. http://cpc.people.com.cn/n1/2020/0911/c64094-31858756.html

[2] 教育部. 高等学校课程思政建设指导纲要. [2020-05-28]. http://www.moe.gov.cn/srcsite/A08/s7056/202006/t20200603_462437.html

[3] 麻秋娟, 冯素香, 张娟, 胡亚楠, 纪永升. 教育现代化, 2019, No. 80, 291.

[4] 段云青, 段志青. 大学化学, 2020,35 (12), 150.

[5] 宦双燕, 王玉枝, 蔡炽, 陈增萍, 唐丽娟, 雷春阳, 刘剑波, 李永军. 大学化学, 2021, 36 (3), 99.

[6] 李爱峰, 王术皓, 贾丽萍, 韩昭君. 大学化学, 2018, 33 (6), 53.

[7] 亱芳, 冯艳茹, 李在洋, 周淑晶. 化工时刊, 2020, 34 (9), 60 .

[8] 王敏. 大学化学, 2020, 35 (5), 180.

[9] 李芳清, 刘淑娟, 曹小红, 马建国. 东华理工大学学报(社会科学版), 2020, 39 (3), 276

[10] 孙寅璐, 姜宏月, 熊英. 大学化学, 2020, 36 (3), 95 .

[11] 刘少贤. 广东化工, 2020, 47 (9), 250.

[12] 孙文亮. 广东化工, 2019, 46 (10), 177.

[13] 李芳清, 刘淑娟, 曹小红, 马建国. 东华理工大学学报(社会科学版), 2020, 39 (3), 276.

[14] 乔校畅, 崔立峰, 金具涛, 范洪波. 广州化工, 2020, 48 (2), 131 .

[15] 陈立钢, 牛娜, 孙明礼. 高教论坛, 2019, No. 4, 58 .

[16] 李翠平, 张宪. 国际公关, 2020, No. 12, 90 .

[17] 蒋自鹏. 广东化工, 2020, 47 (10), 172.

[18] 吴呈珂, 申聪聪. 科教导刊, 2020, No. 32, 133.

[19] 习近平. 全国教育大会重要讲话. [2018-09-10]. http://edu.people.com.cn/n1/2018/0910/c1053-30283652.html

[20] 乔尔·利维. 思想实验: 当哲学遇见科学. 赵丹, 译. 北京: 化学工业出版社, 2019: 1-204. 